\title{
XLIV. Notice respecting the geological structure of the vicinity of Dublin; with an account of some rare minerals found in Ireland
}

\section{William Fitton M.D.}

To cite this article: William Fitton M.D. (1812) XLIV. Notice respecting the geological structure of the vicinity of Dublin; with an account of some rare minerals found in Ireland, Philosophical Magazine Series 1, 39:168, 304-311, DOI: 10.1080/14786441208638129

To link to this article: http://dx.doi.org/10.1080/14786441208638129

曲 Published online: 27 Jul 2009.

Submit your article to this journal $\pi$

ЏII Article views: 3

Q View related articles $\sqsubset$ 
the above, in the pages of your valuahle Journal ; and it in with no small regret that I do relate such cases, and that I see no prospect of the number of these cases being diminished, not even in London. Although here the physician can without delay have the advice of his colleagues, the surgeon the immediate assistance of his professional brethren, and the apothecary may have the advice and assistance of both physician and surgeon almost instantly; yet that wilful perverse desire of pursuing a routine of unsuccessful practice, of keeping the patient from proper assistance, for the purpose of making merchandise of his maladies, by the sale of a few medicines, still prevails and is equally disgraceful to the profession, as it is almost certainly fatal to the patient. In the instance before us, a valuable parent was snatched from a numerous offspring, surely hurried to an untimely grave by a want of that assistance which had been successful in a former case, and which would in all human probability have been again completely successful, had it been applied in proper time.

The operation for hernia is simple, and, when performed with care, in proper time, is almost certainly successful. "Few, if any, would be the fatal cases of this operation, if it was performed sufficiently early*." The result of many years practice, in which the number of operations on persons afflicted with this malady has been very considerable, enables me to speak with well grounded confidence on the success of this operation.

21, Greville-street, Hatton Garden, April 23, 1812.

John Taunton.

XLIV. Notice respecting the Geological Structure of the Vicinity of Dublin; with an. Account of some rare Minerals found in Ireland. By William FitTon, M. D. Communicated by L. Horner, Esq. Secretary to the Geological Society $\uparrow$.

$\mathrm{T}$

$\Gamma_{H E}$ following observations are to be ascribed principally to the late Rev. Walter Stephens. I communicate them to the Geological Society in their present imperfect form, with the hupe that they may attract the attention of mineraJogists to the country in the vicinity of Dublin; for they are sufficient to show that very interesting information may be expected from a correct examination of that district, the

* Hey's Surgical Observations.

+ From the Transactions of the Geological Society, vol. i. with some additions by the Author. 
situation of which renders it easy of access, and affords many advantages to the observer. I shall subjoin to a brief statement respecting the geological structure of that country, an account of some minerals of not very common occurence recently found in Ireland.

The city of Dublin is placed in a flat country, at the distance of about three miles from the sea, and about five miles to the north of a range of mountains forming the verge of an elevated district which extends from thence for more than thirty miles to the south. This district is bounded on the inland or western side by a continuation of the plain of the reighbourhood of Dublin; and its breadth from the sea, which forms its boundary to the east, is generally about four-and-twenty English miles.

The basis of all the plain to the north and west of the mountains above mentioned, appears to be secondary (flotz) limestone.

The mountainous district itself is principally composed of primitive rocks : it is traversed through its whole extent by a broad tract of granite, which, taking its rise on the shore at the south side of Dublin bay, crosses the county of Wicklow in a south-western direction; being bounded by incumbent rocks of great variety, the structure and relations of which, as well as of the granitic mass, are in several places very distinctly exhibited.

The relative extent of the space occupied by the granite, and by the rocks that occur between it and the calcareons country, and the general position of their boundaries, may be understood from the annexed sketch*; in which it is to be remarked, that the places where the boundary is denoted by a dotted line remain still to be explored, the line having been there inserted only for the purpose of illustration.

The granite has been observed in contact with other rocks at the following places in the counties of Dublin and Wicklow : viz. on its eastem boundary,-at Killiney; at the southern extremity of the Scalp; in the bed of the second streamlet which joins that of the Pouerscourt Waterfall, above the fall; from the neighbourhood of Luggelaw to the head of Loch Dan, and from thence to the upper part of Glenmacanass; at Tonelagee; at Aghavanagh in the course of the military road about a mile to the east of the barrack; and at the western branch of the Coolbawn stream on the north-west flank of the mountain Croghan Kinshelat. The

* The sketches referred to in this paper will bo given with our next Number-Plate VII.-EDIToR.

+ Report on the Gold-mine by Messms. Mills and Weaver, Transactions of the Dublin Society, voul. fii. 
boundary of the granite on its northern and western confines is much less regular than on the east; it probably cemmences on the shore of Dublin bay between Booterstown and Blackrock, a mass of limestone having been observed there within a short distance of granite, but the rocks are concealed in the intervening space. The granite comes nearly into contact with limestone again, near the junction of the stream from Dundrum with the river Dodder a little above the village of Milltown; and is visible near schistose beds in the course of the streamlet between Whitechurch and Rathfarnham. It has been observed in contact with schist to the west of the Glen near the head of the Dodder, nearly opposite to a little village called the Brakes of Glassnamucky, but from that place to the west and south, the line of boundary has been very little explored: it passes however very near the granite quarries at Golden-hill, and must run to the east of Porla Phuca and the Glen of Holywood. A junction occurs at Ballyroan on the south-western side of Kilranelagh-hill; and granite has been observed in that neigbbourhood, to the east of Kilranelagh at Knockaderry, and to the south of it at Killalish, Kiltegan, Kilmacart, and near the town of Carlow where the limestone appears, at Brownshill.

The slaty rocks incumbent on the granite in this country are very much diversified in their nature, and they have hitherto been very little examined. On its eastern confjnes, in the places above-mentioned, the prevailing rock is mica slate, the beds of which in general lean towards the granite, their direction being nearly parallel to the line of junction : rocks of the trap kind occur to the west in the neighbourhood of Ballinascorney, and at Kilranelagh ; and columnar rocks of the same description have been observed at Arklow-rock on the south-eastern extremity of the county of Wicklow.

The contry around the village of Bray, which, like that of Wicklow in general, is remarkable for the picturesque beauty of its scenery, presents within a small space several very interesting geological appearances; and those observable at Killiney, first noticed I believe by Dr. Blake of Dublin, will be found particularly deserving of examination: the line of junction, which, as already mentioned, has been traced for several miles across the country, commencing on the shore at the base of Killiney-hill, where schistose beds are to be seen to a considerable extent, reposing upon granite.

On the shore from thence to Dalkey, the granite is traversed 
versed by numerous veins, many of which are themselves composed of granite; and in several instances two such veins, differing from each other and from the mass through which they run, in fineness of grain, and in the proportion of their ingredients, are seen to intersect, one not unfrequently deranging the continuity of the other's direction*. The substance of which these veins consist is perfectly continuous with that of the rock in which they occur, and the surface of fracture passes through both without interruption.

The regularity of the line by which the granite is bounded at Rochestown-hill is highly deserving of atteution. "From the top of the hill a very remarkable ledge of granite runs in a straight line, for upwards of a quarter of a mile, extending from a little below the summit on its south-eastern side in a direction from N.N.E. to S.S.W. This ledge, which is elevated a few feet above the ground to the southeast of it, appears to form the boundary of the granite. The schist in this place seems to run up in a wedge-like form between this ledge and another a little to the eastward, which is much less extensive than the former but corresponds pretty nearly with it in direction, its course being from S.W. by S. to N.E by N.; ant beyond this again still further to the east, another wedge-like branch of the schist runs up between this second ledge and the obelisk hill.",

"In the annexed sketch A denotes the summit of Rochestown hill; $B$, the first ledge of granite; $C$, the second ledge; $D$, the third ledge; $E$, part of the obelisk hillt."

The whole of the Greater Sugar-Loaf mountain is composed of quartz; and the adjoining hill of Stile-bawn and the rocks at the upper part of the Dargle consist of the same substance; which also constitutes the mass of the Lesser Sugar-Loaf mountain, and the summits of Shankhill and of Bray-head, resembling it in figure and in general aspect $\ddagger$. It appears therefore that all the summits of this vicinity which agree in form, are composed of the same material; and it is remarkable that the conical shape characterizes mountains consisting of quartz in various parts

* The mode of intersection of these veins is illustrated by the annexed Sketch, figs. 1, 2,3,4, and 5, representing detached portions of veins observable in different places along the shore at Killiney; figs. 7 and 8 are from large loose blocks on the strand there: these, however, were not the most remarkable that might have been selected.

t Extracted from a note by Mr. Stephens,

$\ddagger$ See the annexed Sketch. 
of the glohe*. I am informed by Mr. Jameson that he has seen in Lusatia detached conical summits composed of that substance; and that the summits of the same figure in the mountains separating Caithness from Sutherland are likewise formed of it ; as are also the Paps of Jura in the Western Islest; and according to Dr. Berger, the mountain Durnhill near the town of Portsoy in Scotland.

The principal mines which have hitherto been opened within the mountainous district near Dublin, are those of copper ore at Cronetiane and Ballymurtagh, the metalliferous waters of which were described in the Philosophical Transactions so long ago as in the year 1757f; and of lead at Glenmalur $\S$, at Giendalogh, at Dalkey, and at Ballycorus rear the Scalp. The stream works commonly called "the Gold-mine" were situate on the north-cast side of the mountain Croghan. Kinshela on the southern verge of the county of Wickjow; and gold has been foùnd within that county at another mountain named CroghanMoira, about eight English miles to the north of that piace $\|$.

The occurrence of Tinstone at the "Gold-mine, where it has been obtained in fragments 9 , is a fact which deserves particular attention; for the probability of the discovery of veins of that valuable ore within a tract of primitive country so extensive as that of Dublin and Wicklow, appears from this circumstance to be considerable.

Porcelain-earth resulting from the decomposition of felspar, has been found at Kilranelagh in the county of Wicklow, in prrity nearly equal to the Cornish "China clay:" and granite is found in a drecomposed staie so commonly in other parts of that county, that this valuable production may with much probability be expected to occur there in other places, and in considerable quantity.

* Siliceous earth in the form of this mineral, and consequently nearly pure, seems to consticute a much greater portion of the earth's surface than some mineralogists have supposed. Humboldt states that near Caxamarca in Peru, a mass of more than nine thousand feet in thickness is exclusively composed of quartz:- he has not mentioned the form of the summits. Tolleau Plysiqute, p. 128.

+ See Walker's Economical History of the Hebrides, vol, ii. p. 392.

Vols, xlvii. and xlviii.

$\$$ The sales of lead, from ore raised and smelted at the Glenmalur mine, mounted during the year ending December 31 st, 1811 , to no less than 9819l. 16s. $2 d$. Irish currency: the weight of metal sold was $6680 \mathrm{cwts}$. 2 qrs.

II Gold is said to have been found also at the King's river, near the village of Holywood, in the county of Wicklow.

Report on the Gold-mine by Messrs. Mills and Weaver. Trans, of Dublin Society, vol. iii.

The 
The flat calcareous country of the neighbourhood of Dublin is very widely extended in various directions: it passes round the mountainous tract above mentioned at its north-western angle, and reaches wirh little interruption, in a southern direcion, through the counties of Kildare and Carlow, to the foot of the hills of the Kilkenny-coal-dintrict; and to the south-west, through the King's and Queen's counties, to the foot of the Sliebh-bloom mountains. It has also considerable exient towards the north and west.

In the parts of this plain more immediately in the neighbourhood of the city, the prevailing rock is that variety of limestone to which $\mathrm{Mr}$. Kirwan has given the name of Calp, of which an excellent description and analysis have been published by the Hon. Mr. Knox*: But in several parts of the fat country, limestone of the ordinary kind abounding in petrifactions is also to be met with.

In the course of the river Dodder, between the village of Milltown and Classon's. Bridge, the calp appears in alternate with beds of granular magnesian-limestone in its characters perfectly resembling some of the substances that occur in various parts of England, which are described as affording a lime injurious to vegetation, in $\mathrm{Mr}$. Tennant's very important paper "on different sorts of lime used in agriculturet." The magnesian stone at Milltown agreeswith the calp and ordinary limestone of the adjoining country in containing petrifactions, although less commonly; and like them also it has frequently imbedded in it masses of siliceous matter, (the "Lydian stone," or a variety of hornstone of Werner.)

The beds of calp and limestone near Dublin, are in general but little inclined to the horizon ; but they often exhibit marks of dislocation; and in some places are singularly inflected, as is remarkably the case with those observable in the bank of the river Liffey, near the bridge at Lucan.

The petrifactions which abound in several parts of this calcareous country $\ddagger$; the beds of calp, and of magnesian limestone, and the siliceous masses above mentioned, afford some of the features that may assist in deciding to which of the "formations" of Werner it is to be referred, or whether it properly belong to any of them : a point or

\footnotetext{
* Traus. of Royal Irish Academy, vol. viii. p. 207.

+Philosophical Tramsactions 1799, or Philosophical Magazine, vol.v. page 209.

t The quarries at St. Doologh's, and in the neighbourhood of Fellrim, affurd very perfect specimens of petrifactions, and in great variety.
} 


\section{Geological Structure of the Vicinity of Dublin.}

some interest in a geological view, from the great extent of the space occupied by limestone in several of the counties near Dublin.

At the peninsula of Howth, which forms the sonthern side of Dublin Bay, grey ore of manganese, and brown iron stone (Minseum of Dublin College, Nos, 1067-8. 887.) bave been obtained in considerable quantity : and a variety of the earthy-black-cobalt-ore of Werner has been found by Mr. Stephens and Dr. Stokes at the south west side of the hill, in the form of a coating of a rich blue colour, which incrusts the fissures of a rock of slate clay, nearly approaching to whetslate (Museum of Dublin College, No. 267): Mr. Tennaut has in this substance ascertained the presence of the oxides of cobalt and of manganese; and the discovery of it is important, as it indicates the probability of the existence of other more valuable ores of cobalt in that neighbourhood.

The heights of very few of the mountains near Dublin have bitherto been ineasured: the onlv published observation with which I am acquainted, being that given in a section annexed to the report on the Gold-mine by Messrs. Mills and Weaver already referred to; where the summit of the mountain Croghan Kinshela is stated to be 2012 feet above the river at Kilcarragh bridge, which is about four miles from the sea. I have myself ascertained by the barometer the heights of the following places in the county of Wicklow, abuve the house of $\mathrm{Mr}$. Greene, at Kirranelagh, viz.-

Lugnaquilla, supposed to be the highest mountain

Feet. of the county .....................2455.1

Cadeen, a mountain detached from the rest, and a conspicuous object from the adjacent flat coun-

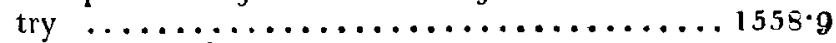

Baltinglass-hill ...................6 681.8

Eadestown-hill ..................... $749^{\circ} \mathbf{4}$

Brusselstown-hill ...................740.1

Kilranelagh-hill $\ldots \ldots \ldots \ldots \ldots \ldots \ldots \ldots \ldots, 705 \cdot 5^{*}$

* The first three heights above mentioned, are each the mean of three observations, the rest are from single observations with two excellent barometers. Mr. Greene's house is (by a single observation) 95,08 feet above the level of the cross roads at the bridge of Tuckmill, a little village on the river Slauey, the elevation of which above the sea will be very woll supplied, when a branch of the Grand-canal shall be extended in this direction, as is now intended. The distance of 'Tuckmill from the sen in a direct line is about eighteen English miles. 
Of the mountains nearest to Dublin :

Feet.

Garrycastle, one of the highest, is ....... 15317

Three-Rock-mountain, adjoining the last ...... 1247.9 above the level of the road at Ballinteer, near the house of Dr. Stokes, the height of which above the sea is considerable.

The highest point of Howth is ......... 567 feet above bigh water mark.

The elevation of the plain country of Kildare, may be judged of from that of the summit level of the Grand-canal, by which it is crossed to the north of the hill of Allen: that level being 264 feet above high water in Dublin Bay, taken from a mark made at the Pigeon-house by order of the Ballast-Office.

[To be continued.]

XLV. Proceedings of Learned Societies. ROYAL SOCIETY.

April 9 th and 16 th. A paper was read on arsenic, by Dr. Lambe of King's Road, Bedford Row, communicated by the late Dr. Garthshore.

The principal object of Dr. L.'s labours on arsenic seems to have been 10 defend an hypothesis proposed hy him, a considerable lime argo, in two successive publications, namely: "An Inquiry into the Origin of Constitutional Diseases," and "Reports on Cancer," in which the Doctor attempted to show the analogy between the action of putrid matter and arsenical poison. The facts of most consequence in the paper read as above to the Royal Society, are the following:

1. One part of charcoal was mixed with ten of white arsenic and twenty of nitre: after deflagration, no signs of carbonic acid could be detected, as would have happened had no arsenic been present.

2. Small quantities of charcoal mixed with white oxide of arsenic had the same effect as upon many other metallic oxides, producing carbonic acid and carbnnic oxide.

3. In the reduction of arsenic by mixing white arsenic, half its weight of subcarbonate of soda, and $\frac{1}{6}$ th part of charcoal, there appeared a peculiar gas in the early stage of the process. It could not be inflamed by a candle, (mixed 